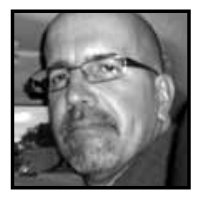

\title{
Of Necessity: Making Decisions About Our Daughter's Early Learning Years
}

\author{
John J. Guiney Yallop, Acadia University
}

\begin{abstract}
Parents play significant roles in their children's learning. Part of those roles include making decisions about when and where their children go to school, or, if those decisions are, or seem, impossible, parents make decisions about how they are going to navigate this apparently inevitable relationship_parents and schools. This article explores some decisions two parents made about their daughter's learning as she headed into school, and during her early school years. The author is aware that not all parents would, or even could, make some of the decisions he made with his partner about their child's learning. The stories contained in this article are offered not as examples of what constitutes good parenting, or good decision-making about relationships with schools, but as reflective pathways into understanding how difference locates us within expected relationships.
\end{abstract}

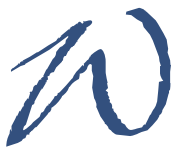

hen our daughter came to us, she was four-and-a-half years old and we were both forty-five. When some of our friends, around the same age as us, were involved in helping their children make decisions about university or college, or were babysitting their grandchildren while the young(er) new parents were out job-hunting, my partner and I were looking at beginning school options for our daughter. We were aware of our difference, this was only one of them, and we loved our new life with our daughter.

One of the first decisions we had to make was when and where to start our daughter in junior kindergarten; we lived in Ontario at the time where junior 
kindergarten was an option. The decision was simplified when one of the social workers we worked with through the adoption process said not to bother because it was more important that our daughter have bonding time with us than it was that she have experiences in school. Although the bond my partner and I formed with our daughter was as close to immediate as one could get (love at first sight), we understood what the social worker was saying; we had also read lots about attachment. So, at least that first decision was easy. Our daughter, who had already begun junior kindergarten in other school settings, skipped the rest of it when she came to us.

To be the stay-at-home parent, my partner had taken a long-term parental leave from his work as a gardener; I returned to teaching elementary school after my two new parent days off. Our daughter stayed home. We cocooned. We read. We played. We did art activities. We explored our backyard, our neighbourhood, and our community. When I was there, we did them all as a family. When I was not there, my partner and our daughter did them together, and then told me about them when I came home. Most of our family and friends understood our need to be alone those first weeks. Not all did, however. We soon learned that becoming parents changed more than what we did together on a day-to-day basis. It changed how people, even how family and friends, responded to us and to our decisions; it changed how they perceived us - how they judged us. This may have been a foreshadowing for some of what was going to happen in schools. Perhaps it was, but we were so in love with our daughter, and with this new role, parenting, we did not, or did not want to, notice.

When the summer of what would have been the end of our daughter's junior kindergarten year was approaching, my partner and I moved back into planning for her beginning school—for senior kindergarten. I was a public school educator who believed strongly in public education; I still do. It made sense, therefore, that we turned to our local public school as the first stop. My partner went in with our daughter to pick up the necessary forms. We wanted her to feel included in this process; going to visit the school was part of the process. My partner's initial impressions, which he chose not to immediately share with me, were not positive. He later told me that the principal looked at them, then looked away and walked back into his office. The secretary, however, was much more inviting and gave them the forms with instructions on how to complete them. We filled out the forms at home and returned them to the school. Our daughter was registered in kindergarten. Then, we started to worry. Would everything be okay? Would she be welcomed? Would her differences be celebrated or would she be made to feel that they were something to not be proud of? Would her teachers be sensitive? Would her principals be kind? 
Were these questions that all parents asked themselves as their child approached school, or were these questions my partner and I were asking because our daughter is adopted and because we are same-sex parents? Were we more worried because our daughter would be entering school in the same school board I had worked in for many years? This was a board in which, and with which, I had engaged in struggles around homophobia and heterosexism, and where I had sometimes heard stereotypical language, and not only from students, about children's differencesincluding about children who were fostered or adopted. It was, eventually, a board I would resign from because I felt I no longer belonged there. When our daughter came to us, I made a promise to myself, and, in doing so, to our daughter, not to fight my equity battles over her body. I was also worried, even fearful, that "the sins of the father," in this particular board, might be visited on the daughter.

It was in the middle of those questions, those worries, those fears, that my partner told me that he had reservations about the neighbourhood school because of the unwelcoming actions of the principal. I decided to call the school and ask a few questions. I spoke with the principal and said that our daughter was registered in kindergarten, that we wanted him to know that she was adopted, and that she was coming from a home with same-sex parents - that she had two dads. The principal immediately told me that that would not be a problem unless our daughter said something about it in the school yard. (Not exactly, or even near, a response I was hoping for. Of course our daughter would be talking about her parents in the school yard; she was talking about us everywhere she went.) I said to the principal that I was hoping for something a little more proactive. I was aware of the equity documents developed by the school board, so I made a point of mentioning the documents, and I asked if our daughter's realities would be included in the curriculum in the school, specifically in her kindergarten classroom. I was assured that the documents were implemented throughout the school, that staff were aware of them and using them. I thanked the principal and said "Good-bye." When I hung up the phone, I told my partner that I did not want our daughter going to that school. He agreed.

My partner and I then made a decision that could be interpreted as protective; it was. It was also a decision that not all parents would, or even could, make; we could, and, because we were not ready or willing to wait and see if things would be okay, to take a risk with our daughter's emotional life, we did. We enrolled our daughter in two weeks of a two-month summer school program at a private school. After the first week, we asked our daughter if she would like to go to this school for kindergarten. She liked that idea. I am aware that I am showing how we manipulated the situation. That being said, had she not liked the private school, we would have 
continued our search. While our daughter was going to be involved in the decision, we were not going to let a five-year-old make decisions that were not safe for her. We were not confident that going to our neighbourhood school would be safe for our daughter. While resilience can be developed from facing adversity, resilience also comes, in part, and, perhaps, of necessity, initially, from having positive experiences, from being valued and celebrated. We wanted our daughter to have lots of those experiences before she, perhaps inevitably, had (additional) less positive ones.

Kindergarten went wonderfully. A memorable moment for us was when the kindergarten teacher told us that our daughter had corrected her one afternoon; when the teacher was telling the students to remind their mommies and daddies to send them with their mitts and hats and winter boots and snowsuits because a big snowfall was expected the next day, our daughter put up her hand and told the teacher that papas had to be reminded too. (My partner is Papa; I am Daddy.) While the school program was somewhat traditional, with a sprinkling of Montessori, it fitted our daughter's needs. While the experience in kindergarten was, overall, a very positive one for our daughter, it should be noted that private schools are not without their problems. In some cases, unless there is strong leadership, problems are not fully acknowledged, or dealt with in transparent ways, perhaps because parents might decide to take their children, and their money, elsewhere. That attitude towards parents is, in my own view, a mistake. Most, although not all, parents who approach schools simply want to be treated respectfully for the very significant role they play in their child's life. These days, as a teacher educator, I tell student teachers to seriously question the negative stories they hear about parents. Parental interest in their child's education is not being bossy or picky, and assertively asking questions and making requests are not examples of aggression. While bossy, picky, and aggressive parents exist, they are not, in my experience and opinion, the majority. They are also not, as well in my experience and opinion, not entirely difficult to deal with when one has wise and supportive administrators.

From kindergarten in a private school, we jumped into French Immersion. This was a decision my partner and I made because we felt (and still feel) that learning a second language (or a third or a fourth) is an important part of an education; also, I taught French Immersion for nine years and I found it to be, for the most part, a very useful and positive experience for students. Our daughter, after the ground is broken, is comfortable in unusual situations. French Immersion is an unusual situation. Our daughter's experience in French Immersion, however, was not the useful and positive experience we had hoped for. Unlike in kindergarten, our daughter had few happy days in her first weeks of grade one. She found her classroom and the 
school environment to be particularly unpleasant. I was working on my doctoral dissertation at the time and, noting my daughter's anxiety, I sometimes invited her to come to university with me-to have a Daddy and Daughter Day. She jumped at each chance. We were also beginning to receive some negative messages that the grade one teacher would write in our daughter's school agenda which came home with her each day; we arranged an interview with the teacher and the principal. The descriptions of the classroom activities, and of our daughter's behaviour, that we were given by the teacher were not close to the descriptions we were hearing from our daughter. While it is not entirely surprising that there would be differences there, it was concerning to us that the relationship appeared so negative. What was also particularly concerning was a question by the principal regarding how we were going to address the matter of our daughter having same-sex parents once that became known to her peers. It was presented as if this was a problem to be dealt with rather than a reality to be aware of.

To us, as parents, the teacher's approach seemed harsh and unresponsive to our daughter's needs. It appeared to my partner and to me that what the teacher was describing as our daughter's behaviour was based on stereotypes of adopted children and other children from "non-traditional" families. (I use quotation marks in the previous sentence because in many respects my partner and I are more traditional than many of our family members and friends, and more so than many of our daughter's friends' parents; I sometimes joke that my partner and I got married before we had our child.) At one point during the meeting, when I started to talk about our daughter's resilience, about some of the experiences she has had and how those experiences form part of what she brings with her to school, much to my surprise I began to cry. Although I had not anticipated this, as my eyes filled with tears and they rolled down over my cheeks, I thought that maybe this would soften the atmosphere-and the approach of the teacher.

When we received our daughter's first grade one report card, however, it was clear that the teacher's approach had not softened; we were shocked. I shared the report card with some colleagues who taught primary students, and even with an administrator of a school with primary grades. The response was unanimous: the report card was unusually negative and harsh for a grade one student, when it should really be focusing on the positive, and be celebratory. My partner and I felt that we could not afford a negative year so early in our child's school life. We might have felt differently had we been birth parents and had our daughter's life, to that date, been relatively uneventful. We talked to our daughter about changing schools. While she did not want to leave her before- and after-school program (which she loved, which 
was not in the school, and which she was in because my partner had returned to work), when we mentioned the possibility of returning to the school where she did kindergarten, our daughter was thrilled.

The next two terms in grade one were enormously positive. The teacher was remarkable in her ability to recognize and celebrate the unique gifts of her students. When the year concluded, she gave each of the children a pendant with a word on it. Our daughter's pendant had the word "Pride." "My family celebrates Pride," our daughter excitedly said to the teacher. "I know," the teacher replied. "That's why I picked that one for you."

So, if things were working, why change? Despite the costs financially, we decided to continue with the private school for grade two because the benefits for our daughter emotionally were huge. Again, I am aware that this is a decision that not all parents could make, or would make even if they could. For us, however, it was a matter of necessity; we wanted our daughter to have a positive foundation in learning. To do that, we felt it necessary to, as much as possible, control the variables which had an impact on her learning.

Things did change, however, near the end of the first term of the following year, when our daughter's grade two teacher began sending home enormous amounts of homework-mostly rote math questions. We suspected that this relatively new teacher might be trying to prove herself in what some wanted to be known as an academically challenging school. We told our daughter's teacher that we understood that she may be getting some pressure from some parents to send home lots of homework, but that she would not get any such pressure, and no criticism, from us if a lot of homework did not come home; in fact, we informed the teacher that we would prefer to not have any homework at all for our daughter, or to have very little. We felt that after-school play time was an important part of learning, and we did not want our evenings crowded with activities that came from outside our family's initiatives.

The grade two teacher saw things differently. She said that she was worried that if our daughter did not do this homework, she would not be prepared for future grades in school, and would have problems later in her life. I was a bit taken aback, but I assured the teacher that our daughter's future success was our concern, as her parents, and, since we were not worried, that she, the teacher, should just focus on what our daughter could do in school in grade two and let us, the parents, handle life at home, including any work expected. Despite an agreement to ease off, the homework was soon coming again. Our daughter was beginning to show signs of stress-a 
situation that we felt was not appropriate for a seven-year-old. We then took a step we had not originally planned on. After a conversation with our daughter, we withdrew her from school to begin homeschooling. This was possible because, although my partner had returned to full-time work at this time, I was, as noted above, completing my doctoral dissertation; I was also teaching one course at the university.

When we were homeschooling, I often took our daughter with me to my course. Our reading time together extended well beyond bedtime. Our daughter began to write stories about her experiences, including trips we took. We put a moratorium on math for a few months, because that seemed to be the major cause of the anxiety generated by the excessive rote activities - in school and for homework. We began to reintroduce math as part of regular life. My partner is the primary cook in our family, so our daughter began helping in the kitchen. She loved measuring ingredients and dividing portions. She counted out the various items my partner required for whatever meal they were preparing, or for whatever special creation they were baking. She weighed items when something more exact was necessary. My partner took our daughter grocery shopping. He talked with her about prices and why he was making some decisions based on those prices. Looking back at this practice, I would make one change. My partner and I tended to pay for purchases with debit or credit cards. When our daughter saw this, she did not make clear connections between the groceries in the basket and the money we were earning. This was evident one day when we were talking about making some big purchase and my partner said, "We don't have enough money for that." Our daughter replied, "But, you can buy it with your card." We explained that before you can take money out of a bank account, you must put money into it. We also explained that even purchases made with a credit card had to be paid for later. It was at this time that we began to give our daughter a regular allowance. This, we feel, helped her develop a further appreciation of the role money plays in our lives.

One of the most remarkable experiences of homeschooling was connecting with other homeschooling families. In the city where we lived, there was an established network of homeschooling families. This was new to us. We got our name on the mailing list and listserv. We met for activity days, book exchanges, and excursions. The children played together and formed friendships. The parents, a diverse group whose reasons for making the decision to homeschool their children were equally diverse, including some reasons that I would have disagreed with, were very welcoming to my partner and to me, and to our daughter. The commitment of those parents to give their children the best possible learning opportunities, and to ensure that those opportunities would enable their children to learn in their own unique ways, 
was impressive. Some of those parents were also making the decision to homeschool without the level of financial resources my partner and I were able to draw on. The relationships among the parents were collaborative, not competitive. The children saw those relationships and, as all children do, they learned values from them.

Our daughter enjoyed homeschooling. As well as interactions with other children in activities outside the home, and some individual outside activities also, she had activities at home. Some of those activities were increased play times-alone or with my partner and/or me. Other activities were more formal in our informal setting. We bought grade-level activity books and worked our way through them. When we travelled, even on very brief trips, we brought the activity books with us. When our daughter travelled with me to university, she brought those activity books and worked on them in the backseat of the car, and at a desk in the back of the classroom while I taught new teachers about teaching language arts. She also brought some of her story books and read them. The activity books included math activities; the moratorium was now over. We bought a family membership at the Royal Ontario Museum and went there frequently. We spent more time at the library, and we signed out books at each visit. We also watched television and movies, using "screen time" as educational time. Screen time included using the computer to search for educational activities. Our daughter concluded grade two as a homeschooler.

As what would likely be the final year of my doctoral program approached, with my dissertation nearing completion and knowing that I would be preparing for my dissertation defence, my partner and I began to look at employment opportunities for me-both positions and locations. I investigated the positions and the qualifications for the positions, while my partner studied the location-the university and the town or city where we would be moving our family. We talked with our daughter about the possible move. We assured her that she would be involved in all of the processes for the move. We had another decision to make. Would we continue with homeschooling or find another school for grade three? Our daughter wanted to continue homeschooling. I was reluctant. As I look back at it, and as I shared with my students at the time, I think I was concerned about being seen as the teacher educator with a child who was school-phobic. I believe that schools do (or can) make a (positive) difference in children's lives. Why were we not sending our daughter to school to experience that difference? I was also, I think I convinced myself, worried that our lives would become busier as I approached the end of my dissertation. I had accepted teaching two more courses at my university, bringing the total to three. The commute was long. My partner was working full-time. 
We decided to explore other options besides homeschooling, without ruling out homeschooling as an option for grade three. We did, however, rule out the possibility of public school in our community. Two failed attempts (failed because of what could be characterized as unwelcoming behaviour, at best, in the schools) were all that we were willing to accept from one school board, particularly when we already had our doubts-gut feelings that we should have been more trusting of to begin with. We also decided that returning to the private school where our daughter had already spent some of her schooling was not an option, because the school administration had not responded well to our decision to homeschool when our daughter was being given excessive homework despite our requests to have the homework ceased or reduced. We looked for another private school. We found one that seemed an interesting possibility and we asked if we could bring our daughter in for a visit. The small school was welcoming from the start. Without even asking, we were told that there would be no homework because the teacher believed home play time was part of learning. We started with two weeks of a summer program, which we increased to four weeks because our daughter liked it so much. We registered our daughter for the year. It was an enormously positive year. In many respects, we credit our daughter's grade three teacher, and the teacher's assistant, with playing a significant role in dismantling our daughter's phobias for school, and for math in particular. We credit the French teacher at that school with playing a significant role in restoring our daughter's delight in learning a second language. When I would ask my daughter if she wanted to take a Daddy and Daughter Day, and come with me to university, she would say that she did not want to miss school. I found myself bribing with a promise to stop in at the gas station where she could buy a stuffy for a "twooney."

Our daughter is currently in a public school in the community where we moved and where I now teach at a university. My partner and I frequently evaluate our decision about schooling, not out of any sense of regret for decisions made, but out of a need to keep asking ourselves if this is the best decision for our daughter at this time and place in her life. And we are, admittedly, protective, although we are also aware that our daughter is now often able, and even wanting, to fight her own battles. Because we involve her in these decisions about her life, we need to know our daughter's views as well.

As parents, we, not just my partner and I, but all parents, want to make only the best decisions for our children. Decisions about our children's education are not ones that are peripheral to parenting, but ones that go to the core of our hearts and lives as parents because we know, or at least we want to believe, that those decisions have such an enormous impact on our children. Because my own biological family, 
the family I grew up in, was poor, the choices in regards to where and when I went to school would have been limited, or non-existent, even if we had had more than the one school in the community. Unlike my parents, I had other choices to make, with my partner and with our daughter, about the latter's schooling. The decisions my partner and I made in our daughter's early learning years were neither arbitrary nor final; they were responses to experiences, and rooted in love. Like my own parents, the fish plant worker and the housewife, neither of whom completed elementary school, the experienced elementary school teacher and doctoral student (me) and the collegeeducated-award-winning gardener (my partner) did the best we could. I hope.

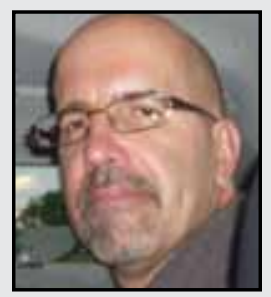

John J. Guiney Yallop is a parent, a partner, and a poet. He is currently an Assistant Professor in the School of Education at Acadia University. His research includes poetic inquiry, narrative inquiry, autoethnography, and performative social science. He uses these methodologies to explore identities, communities, and emotional landscapes. His writing has appeared in literary and scholarly journals and in edited books. Dr. Guiney Yallop has presented his work at national and international conferences, as well as at poetry readings and art shows. 